\title{
A Short Review on Applicable Processes for Removal of Phenol from Water
}

\author{
Mohamed Gar Alalm* \\ Department of Public Works Engineering, Mansoura University, Egypt
}

Submission: March 15, 2018; Published: April 05, 2018

*Corresponding author: Mohamed Gar Alalm, Department of Public Works Engineering, Faculty of Engineering, Mansoura University, Mansoura, Egypt, 35516, Tel: +20502244403; Email: mohamed.alkalla@ejust.edu.eg

\begin{abstract}
In this paper, the recent advances in removal of phenol from water are briefly reviewed. The removal of phenol could be attained by adsorption, photocatalysis, ozonation, and different forms of Fenton reactions. However, the choice of the appropriate method is dependent on the initial concentration of phenol. Emphasis is given to the reports that include optimization of operating conditions and cost estimation. The merits and limitations were discussed to clarify the favorability of each method.
\end{abstract}

Keywords: Adsorption; Fenton; Phenol; Photocatalysis

Abbreviations: AOPs: Advanced Oxidation Processes; PAC: Powdered Activated Carbon; GAC: Granular Activated Carbon; PHAp: Porous HydroxyApatite; FAp: Fluoro Apatite; WC: Wood Charcoal; RHA: Rice Husk Ash.

\section{Introduction}

Phenolic compounds exist in the wastewater of many industries such as resins, pharmaceuticals, paint, petrochemical products, and olive mills [1]. Dermal exposures to phenol are reported to cause skin damage, eye irritation, and problems to mucous membranes. Moreover, phenol is toxic to humans via oral exposure [2]. Phenolic compounds and other bio-recalcitrant organics are poorly removed in conventional biological treatment due to their toxicity that simply kill the microorganism in activated sludge systems [3]. Accordingly, many researchers tend to investigate different chemical methods for removal or degradation of biorecalcitrant pollutants [4]. These methods include adsorption by activated carbon and polymeric adsorbents, and Advanced Oxidation Processes (AOPs) like ozonation, Fenton reactions, and photocatalysis [5-8]. The choice of the appropriate method should be based on efficiency, costs, and influent characteristics such as $\mathrm{pH}$ and initial concentration $[9,10]$.

This paper aims to briefly review the recent advances of different methods that have been reported for removal of phenol from water. The applicability and merits of each method have been focused.

\section{Discussion}

\section{Adsorption}

Adsorption could be the first choice for removal of phenol from water because of its high efficiency and easy application using suspended Powdered Activated Carbon (PAC), Granular
Activated Carbon (GAC) columns, or recent developed adsorbents [11]. Bahdod et al [12] studied the removal of phenol by three apatite adsorbents (Porous Hydroxy Apatite (PHAp) and crystalline hydroxyl- (HAp) and Fluoro Apatite (FAp)) [12]. The best obtained adsorption capacity was $8.2 \mathrm{mg} / \mathrm{g}$ with the prospect of thermal regeneration. Aghav et al. attained $88 \%$ removal of phenol using different carbonaceous adsorbents such as Wood Charcoal (WC) and Rice Husk Ash (RHA) [1]. Adsorption of phenol is applicable when the concentration of phenol is relatively low $(<100 \mathrm{mg} / \mathrm{L})$. In this case, the amount of needed adsorbent is appropriate, and hence the adsorption will be cost-effective. Some industries like coal processing, resins, and refineries produce highly contaminated water with phenol concentration up to $6000 \mathrm{mg} / \mathrm{L}$. Using adsorption for removal of high phenol concentrations requires considerable amount of adsorbents. In addition, the disposal or regeneration of the contaminated adsorbents will be a concern [13]

\section{Advanced oxidation processes (AOPs)}

The advantage of AOPs is the destruction of contaminants by degrading them into benign end products such as $\mathrm{CO}_{2}$, and $\mathrm{H}_{2} \mathrm{O}$ [14]. Gar Alalm et al. [15] investigated the removal of phenol by solar photocatalysis using naked titanium dioxide $\left(\mathrm{TiO}_{2}\right)$ and $\mathrm{TiO}_{2}$ supported on activated carbon $\left(\mathrm{TiO}_{2} / \mathrm{AC}\right)$ [15]. They found that complete degradation of phenol and its intermediates could be attained by $\mathrm{TiO}_{2} / \mathrm{AC}$ faster than using naked $\mathrm{TiO}_{2}$. They estimated the total cost for removal of phenol using their method by $3.19 € / \mathrm{m}_{3}$. Esplugas et al. [16] studied the 
degradation of phenol by different combination of ozonation, UltraViolet light (UV), and hydrogen peroxide $\left(\mathrm{H}_{2} \mathrm{O}_{2}\right)$ [16] Complete degradation of phenol with initial concentration of $100 \mathrm{mg} / \mathrm{L}$ was attained using ozonation in about $80 \mathrm{~min}$. They found that other combinations like $\mathrm{O}_{3} / \mathrm{H}_{2} \mathrm{O}_{2}, \mathrm{O}_{3} / \mathrm{UV}$ and $\mathrm{O}_{3} / \mathrm{UV} /$ $\mathrm{H}_{2} \mathrm{O}_{2}$ did not enhance or accelerate the degradation of phenol. Ayodele et al. [17] and Gar Alalm et al. [18] investigated the degradation of phenol using photo-Fenton process $[17,18]$ Photo-Fenton reaction revealed high efficiency even at high initial concentrations $(>500 \mathrm{mg} / \mathrm{L})$. The total cost for removal of phenol by solar photo-Fenton reaction was estimated by $2.54 € / \mathrm{m}_{3}$. Another Fenton process that reported to achieve efficient degradation of bio-recalcitrant pollutants is electroFenton $[6,19]$. Radwan et al. [20] found that phenol could be completely degraded by electro-Fenton process using sacrificial or non-sacrificial anodes [20]. The current intensity was the key factor that influenced the degradation efficiency. The key limitation of Fenton processes is the high amount of produced sludge, but they are still preferred because of their high efficacy and low cost especially when the initial phenol concentration is high.

\section{Conclusion}

Several methods could be applied for removal of phenol from water including adsorption, photocatalysis, ozonation, and Fenton reactions. The application of adsorption is limited to low phenol concentrations. Ozonation and photo catalysis are suitable for phenol degradation but the cost efficiency and application to high phenol concentration are still challenges. Fenton processes are the most appropriate choices in case of high phenol concentration in terms of efficiency and costs. However, the high amount of produced sludge is still a concern.

\section{References}

1. Aghav RM, Kumar S, Mukherjee SN (2011) Artificial neural network modeling in competitive adsorption of phenol and resorcinol from water environment using some carbonaceous adsorbents. J Hazard Mater 188(1-3): 67-77.

2. Carta R, Desogus F (2013) The enhancing effect of low power microwaves on phenol oxidation by the Fenton process. J Environ Chem Eng 1(4): 1292-1300.

3. Gar Alalm M, Tawfik A (2014) Solar photocatalytic degradation of phenol in aqueous solutions using titanium dioxide. Int J Chem Nucl Metall Mater Eng 8 (2): 1-4.

4. Busca G, Berardinelli S, Resini C, Arrighi L (2008) Technologies for the removal of phenol from fluid streams: A short review of recent developments. J Hazard Mater 160(2-3): 265-288.

5. Gar Alalm M, Ookawara S, Fukushi D, Sato A, Tawfik A (2016) Improved W03 photocatalytic efficiency using $\mathrm{ZrO} 2$ and Ru for the degradation of carbofuran and ampicillin. J Hazard Mater 302: 225-231.
6. Gar Alalm M (2016) The performance of electro-Fenton oxidation in the removal of pesticides from wastewater using stainless steel electrodes. Int Proc Chem Biol Environ Eng 98(2): 9-14.

7. Gar Alalm M, Tawfik A, Ookawara S (2015) Comparison of solar $\mathrm{TiO}_{2}$ photocatalysis and solar photo-Fenton for treatment of pesticides industry wastewater: Operational conditions, kinetics, and costs. J Water Process Eng 8: 55-63.

8. Gar Alalm M, Tawfik A, Ookawara S (2015) Degradation of four pharmaceuticals by solar photo-Fenton process: Kinetics and costs estimation. J Environ Chem Eng 3(1): 46-51.

9. Ashery AF, Radwan K, Gar Alalm MI (2010) The effect of pH control on turbidity and NOM removal in conventional water treatment. Int Water Technol J 1(2): 1-16.

10. Gar Alalm M, Nasr M, Ookawara S (2016) Assessment of a novel spiral hydraulic flocculation/sedimentation system by CFD simulation, fuzzy inference system, and response surface methodology. Sep Purif Technol 169: 137-150.

11. Gar Alalm M, Nasr M (2018) Artificial intelligence, regression model, and cost estimation for removal of chlorothalonil pesticide by activated carbon prepared from casuarina charcoal. Sustain Environ Res.

12. Bahdod A, El Asri S, Saoiabi A, Coradin T, Laghzizil A (2009) Adsorption of phenol from an aqueous solution by selected apatite adsorbents: Kinetic process and impact of the surface properties. Water Res 43(2): 313-318.

13. Gar Alalm M, Tawfik A, Ookawara S (2016) Enhancement of photocatalytic activity of $\mathrm{TiO} 2$ by immobilization on activated carbon for degradation of pharmaceuticals. J Environ Chem Eng 4(2): 19291937.

14. Gar Alalm M, Tawfik A (2013) Fenton and solar photo-fenton oxidation of industrial wastewater containing pesticides, 17 th Int Water Technol Conf p. 1-11.

15. Gar Alalm M, Tawfik A, Ookawara S (2014) Solar photocatalytic degradation of phenol by $\mathrm{TiO} / \mathrm{AC}$ prepared by temperature impregnation method. Desalin Water Treat 57(2): 835-844.

16. Esplugas S, Gimenez J, Contreras S, Pascual E, Rodriguez M (2002) Comparison of different advanced oxidation processes for phenol degradation. Water Res 36(4): 1034-1042.

17. Ayodele OB, Lim JK, Hameed BH (2012) Degradation of phenol in photo-Fenton process by phosphoric acid modified kaolin supported ferric-oxalate catalyst: Optimization and kinetic modeling. Chem Eng J 197: 181-192.

18. Gar Alalm M, Tawfik A, Ookawara S (2014) Investigation of optimum conditions and costs estimation for degradation of phenol by solar photo-Fenton process. Appl Water Sci.

19. Annabi C, Fourcade F, Soutrel I, Geneste F, Floner D, et al. (2016) Degradation of enoxacin antibiotic by the electro-Fenton process: Optimization, biodegradability improvement and degradation mechanism. J Environ Manage 165: 96-105.

20. Radwan M, Gar Alalm M, Eletriby H (2018) Optimization and modeling of electro-Fenton process for treatment of phenolic wastewater using nickel and sacrificial stainless steel anodes. J Water Process Eng 22: 155-162. 
(C) (i) This work is licensed under Creative (c) Commons Attribution 4.0 License

\section{Your next submission with Juniper Publishers} will reach you the below assets

- Quality Editorial service

- Swift Peer Review

- Reprints availability

- E-prints Service

- Manuscript Podcast for convenient understanding

- Global attainment for your research

- Manuscript accessibility in different formats

( Pdf, E-pub, Full Text, Audio)

- Unceasing customer service

Track the below URL for one-step submission https://juniperpublishers.com/online-submission.php 